\title{
Hajj Financial Management in the Maqāṣid Sharīah Perspective
}

\author{
Ulfah Alfiyanti', Achmad Firdaus ${ }^{2}$, Dede Abdul Fatah ${ }^{3}$ \\ 1,2IAI Tazkia, Bogor - Indonesia, ${ }^{3}$ Politeknik Negeri Jakarta - Indonesia \\ 1ulfah_alfi@yahoo.com, 2achmad.firdaus@tazkia.ac.id,3achmad50661@gmail.com
}

\begin{abstract}
Abstrak
This paper analyzes the management of the pilgrimage fund to the concept of Islamic wealth management and the management of the pilgrimage fund and its compliance with the maqāsid al-sharīah. The first is done by analyzing the management of haij funds by BPKH on the management of Islamic wealth. The second is done through interviews with academics, regulators, experts and practitioners. Descriptive processing is done through Strategic Assumption Surfacing and Testing (SAST). The analysis is done by selecting the 'important' and 'definite' variables. The results showed that the determinants of Hajj fund management according to Islamic wealth management were contracts, zakat and transparency. Hajj fund management policies for the protection of religion, including the setting of a fair and transparent haj quota, building infrastructure facilities for the pilgrimage, ensuring terms and conditions Life protection through the use of halal vaccines, providing and funding Hajj monitors, improving catering, lodging, transportation and health services and providing congregational data to the Ministry of Health. Protection of reason through improving the quality of rituals. Protection of assets through transparency in the management of hajj funds, direct investment in harmony with sharia, and management of hajj funds in Islamic banking.
\end{abstract}

Keywords: $\quad$ BPKH; hajj fund; maqāṣid al-sharīah; Strategic Assumption Surfacing and Testing (SAST)

Tulisan ini menganalisa pengelolaan dana haji terhadap konsep manajemen kekayaan Islam dan kebijakan manajemen dana haji dan kesesuaiannya dengan maqāșid alsharīah. Pertama dilakukan dengan menganalisis pengelolaan dana haji oleh BPKH terhadap manajemen kekayaan Islam. Kedua dilakukan melalui wawancara dengan para akademisi, regulator, pakar dan praktisi. Pemrosesan deskriptif dilakukan melalui Strategic Assumption Surfacing and Testing(SAST). Analisis dilakukan dengan memilih variabel 'penting' dan 'pasti'. Hasil penelitian menunjukan bahwa penentu pengelolaan dana haji menurut manajemen kekayaan Islam adalah kontrak, zakat dan transparansi. Kebijakan pengelolaan dana haji untuk perlindungan agama, meliputi pengaturan kuota haji yang adil dan transparan, membangun fasilitas infrastruktur untuk ibadah haji, memastikan syarat dan ketentuan. Perlindungan jiwa melalui penggunaan vaksin halal, menyediakan dan mendanai pengawas haji, meningkatkan layanan katering, penginapan, transportasi dan kesehatan dan memberikan data jemaat ke Kementerian Kesehatan. Perlindungan akal melalui peningkatan kualitas ritual. Perlindungan harta melalui transparansi dalam pengelolaan dana haji, investasi langsung selaras dengan syariah, dan pengelolaan dana haji pada perbankan syariah.

Kata Kunci: BPKH; dana haji; maqāṣid al-sharīah; Strategic Assumption Surfacing and Testing (SAST) 


\section{Introduction}

Data from the Indonesian Ministry of Religion (figure 1) shows that the interest of Indonesian Muslims to perform the pilgrimage has increased. In 2005 there were 189,842 worshipers and increased in 2011 to reach 199,848 worshipers. In 2013, the Government of Saudi Arabia renovated the expansion of the thawaf place so that a policy of reducing the pilgrimage quota by $20 \% .{ }^{1} \mathrm{At}$ that time, the State of Indonesia received a quota of 168,800 worshipers.

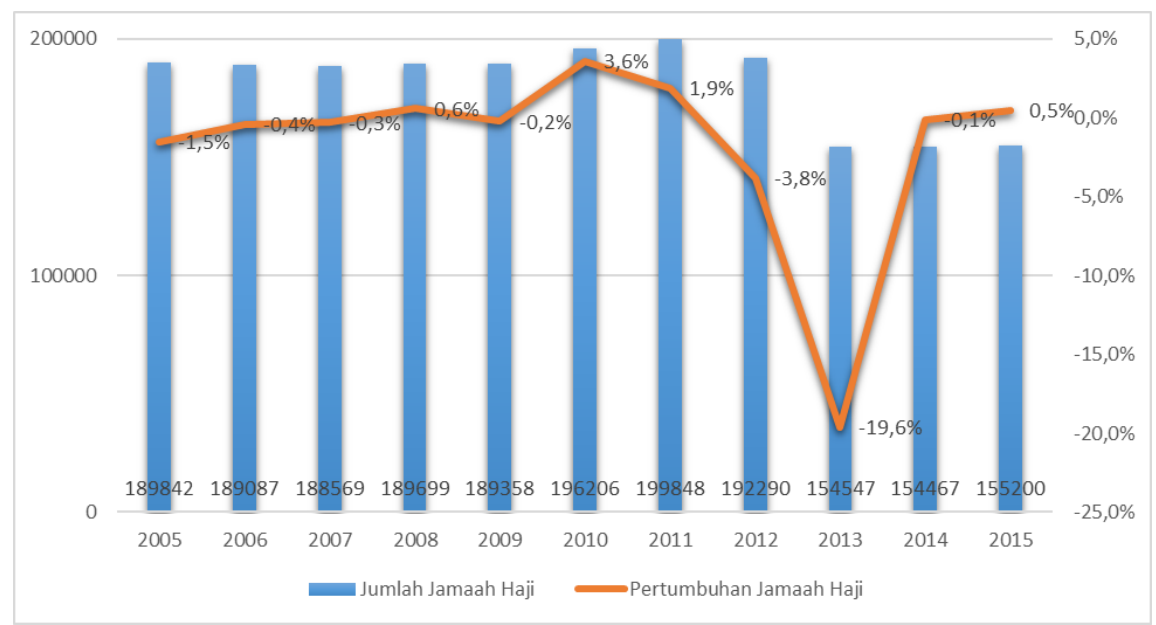

Figure 1. Development of Indonesian Hajj Pilgrims for 2005 - 2015

(Source: Processed from the Ministry of Religion)

Subadi explained that the Hajj service in Indonesia was in accordance with the law. However, Hajj services in Malaysia are much better. This is due to the lack of detailed management of the pattern of Hajj funds management. Meanwhile, the pilgrimage funds are getting bigger and the waiting times are getting longer, requiring professional, permanent arrangements and can provide a mandate to the Ministry of Religion to carry out hajj financial management.2

The total amount of haj funds managed by the Ministry of Religion of the Republic of Indonesia until 2013 reached 64.5 trillion Rupiah (figure 2). Since

\footnotetext{
${ }_{1}^{1}$ Kementerian Agama Republik Indonesia, Laporan Evaluasi Penyelenggaraan Ibadah Haji 2013, 20a13.

2Subadi, Implementasi Kebijakan Pelayanan Haji Pada Kantor Kementerian Agama Kabupaten Bintan Provinsi Kepaulauan Riau, 2013.
} 
2004, the Ministry of Religion has put in place an initial deposit payment system for the cost of organizing the hajj pilgrimage (BPIH). During the 2 years collected, the pilgrimage fund practically became a silent asset. Deposit BPIH settles at the Deposit Recipient Bank (BPS). Hajj funds settle to Bank Indonesia without getting added value it, only gets a guarantee of conversion to US \$. In 2006, BPIH began to be managed in the form of demand deposits, deposits and savings at commercial banks. After that, since 2009 the pilgrimage funds began to be invested in the Indonesian Hajj Dana Sukuk (SDHI). Investments in sukuk provide greater benefits than deposits, so the value of benefits for pilgrims increases. Based on data from the Directorate General of Debt Management (DJPU), the development of SDHI always increases.

The outstanding value of SDHI as of December 2015 was IDR 36.70 trillion. Since its issuance in 2009 the amount of placement of hajj funds in sukuk amounted to Rp 2.7 trillion, increasing to Rp 35.78 trillion in 2012. Placement of hajj funds in sukuk decreased at the end of 2013, because the sukuk value of Rp 4.25 trillion matured in May 2013 and was not rolled over (placed back on deposit). An increase in the number of outstanding SDHIs has increased due to the placement of Hajj funds in government instruments, namely low-risk sukuk. This gives a greater profit than deposits. So the value of expediency for pilgrims can increase. Meanwhile, the placements in current accounts and deposits increased due to increased banking returns. ${ }^{3}$

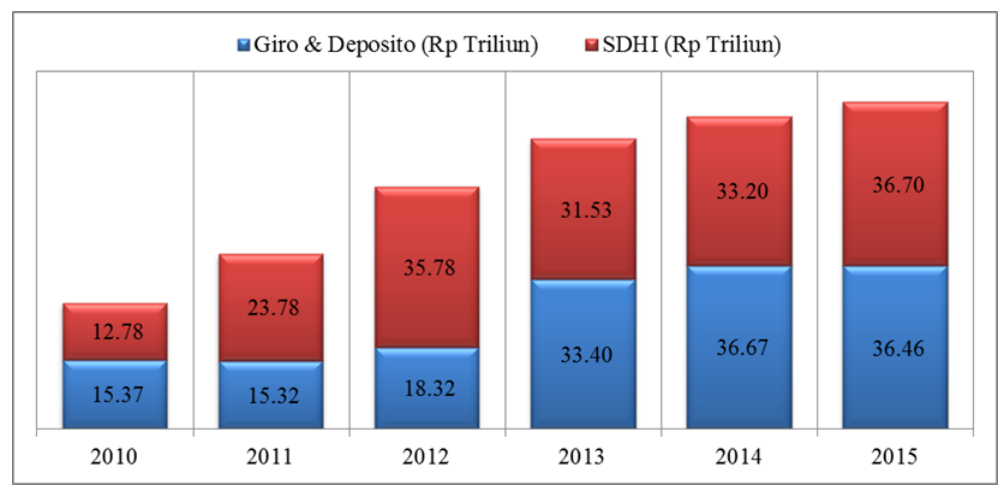

Figure 2. Placement of Hajj Funds for 2010 - 2015

(Source: djpu.depkeu.go.id and Ministry of Religion.go.id, processed)

\footnotetext{
${ }^{3}$ Kementerian Agama Republik Indonesia, 'Laporan Keuangan Penyelenggaraan Ibadah Haji Tahun 2013', 2014.
} 
The BPIH optimization step was realized by forming the Hajj Financial Management Agency (BPKH) through Law No. PKH. 34 of 2014. The presence of this law is motivated by the incomplete regulation and provisions on the management of hajj funds as stipulated in the previous law. The law becomes a legal umbrella for efforts to manage Hajj funds to be more professional and useful. ${ }^{4}$ Professional and beneficial Hajj fund management is expected to be able to support the implementation of the hajj pilgrimage which is more professional, trustworthy, transparent and optimal.

The formation of BPKH in 2014 was far behind compared to Malaysia's Hajj Tubes in 1963. ${ }^{5}$ Tabung Haji acts as a savings institution for Malaysian Muslims to fulfill the obligations of the hajj pilgrimage. Tabung Haji provides fast and professional services for pilgrims. Services are achieved through efficient savings and investment management. Tabung Haji is one of the models of Islamic financial institutions (LKS) that contribute to the development of the Malaysian economy. ${ }^{6}$

Tabung Haji have evolved efficiently by adopting participatory internal management, contemporary marketing techniques and technology.7 Tabung Haji applies sharia principles in the management of savings, investments and Hajj services. The management of Tabung Haji is grouped into 2 categories: first, managing saving funds and withdrawing funds. Second, investment management.

Shuhaimi explained that Tabung Haji grew fantastically. In 1963, Tabung Haji had 1,281 savers with a total savings of US \$ 15,400 through three branch offices. At the end of 2009, Tabung Haji managed 26,000 pilgrims through five airports in Malaysia. Tabung Haji manages more than 5 million savers. ${ }^{8}$ The

\footnotetext{
${ }^{4}$ Abimanyu A., 'Pengelolaan Dana Haji Dulu, Sekarang Dan Masa Depan', Realita Haji (Jakarta, 2014).

${ }^{5}$ Khaliq Ahmad, Mustafa Omar Mohammed, and Dzuljastri Abdul Razak, 'Case of Pilgrimage Funds Management Board (Lembaga Urusan Tabung Haji)', IIUM Journal of Case Studies in Management3, no. 2 (2012): 17-31, https://doi.org/10.1142/9789814508988.

${ }^{6}$ Mohd. Shuhaimi Ishak, Tabung Haji as an Islamic Financial Institution for Sustainable Economic Development', in 2011 2nd International Conference on Humanities, Historical and Social Sciences IPEDR vol.17,2011,236-40.

${ }^{7}$ Ahmad, Mohammed, and Razak, 'Case of Pilgrimage Funds Management Board (Lembaga Urusan Tabung Haji)'.

8Ishak, 'Tabung Haji as an Islamic Financial Institution for Sustainable Economic Development', 236-240.
} 
Tabung Haj service office serves savers totaling more than 345 locations throughout Malaysia with a total savings of 8 billion US \$. In 2018, Tabung Haji recorded a net asset of 59.5 billion ringgit or around IDR 180 trillion. The return on investment reached IDR 8 trillion. ${ }^{9}$

The establishment of BPKH through Law No. 34 of 2014, technically clarified in Government Regulation No. 5 of 2018 concerning the Implementation of Law Number 34 of 2014. BPKH has the duty to manage hajj finances including revenues, expenses and wealth (Article 7). The sources of BPKH revenue are explained in Article 8. The sources of BPKH expenditure are explained in Article 19. The sources of wealth are explained in Article 40.

As a sharia financial manager, BPKH is expected to be able to manage finance according to sharia asset management principles. ${ }^{10}$ It is necessary to examine the suitability of BPKH's duties in managing hajj finances which include income, expenditure and wealth (Article 7) to the principles of sharia asset management. On the other hand, BPKH in formulating policies (Article 3), needs to harmonize policies with the objectives of sharia (maquassid sharīa). This study aims to, first, analyze the suitability of BPKH hajj financial management to the principles of sharia asset management and second, the suitability of hajj financial management policies towards maqashid sharia.

\section{Hajj and Suitability of BPKH Hajj Financial Management with Sharia Treasure Management}

Hajj literally means آَََْصصْدُ, meaning intentional or intentional.11 Meanwhile, according to the syara term, Al-Khin mentioned that the hajj is

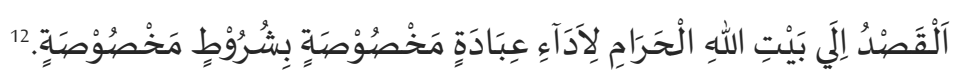

Intends to visit Baitullah to carry out special worship with special conditions

The specific worship referred to is wuqūf in 'Arafah, țawaf, sa'i, tahallul and other worship services. Most of the scholars agree that there are five special requirements for the pilgrimage, namely: Moslem, bāligh, common sense,

\footnotetext{
9Tabung Haji, ‘5 Years Data \& Statistics’ (Malaysia, 2019).

10Zurina Shafii, Zarinah Yusoff, and Shahizan Md Noh, Islamic Financial Planning and Wealth Management (Kuala Lumpur: IBFIM, 2013).

${ }^{11}$ A.W. Munawwir and Muhammad Fairuz, Kamus Al-Munawwir Indonesia-Arab Terlengkap (Pustaka Progressif, n.d.), 237.

12 Muștafā Al-Khīn, Muștafā Al-Bughā, 'Alī al-Sharjabī, Al-Fiquh Al-Manhajī 'Alā Madhhab Al-Imām Al-Shäfi'î, 4 th ed. (Damaskus: Dāral-Qalam, 1996).113.
} 
independent and capable. ${ }^{13}$ While Al-Khin mention there are six conditions for the pilgrimage. The difference lies in amn al-tariq, namely the fear of war that causes it cannot leave. In the end the pilgrimage is not required. ${ }^{14}$

The implementation of the hajj pilgrimage in Indonesia is regulated in Law No. 17 of 1999 concerning the Organization of Hajj. ${ }^{15}$ In the law it is stated that what is meant by the organization of the pilgrimage is a series of activities including the fostering, service, and protection of the implementation of the pilgrimage. The activity management team is formed by the Minister of Religion (Article 8). The law is the basis for the establishment of the Community Endowment Fund Management Agency (BPDAU). BPDAU has the main task of planning, organizing, managing funds, and utilizing the Community Endowment Fund (Article 11).

Law No. 17 of 1999 perfected into Law No. 132008 Regarding the Implementation of Hajj. ${ }^{16}$ Improvements were made including the principles of the implementation of the pilgrimage, namely justice, professionalism and accountability with the principle of non-profit (Article 2), the formation of the Indonesian Hajj Supervisory Commission - KPHI (Article 12), and the rights and obligations of pilgrims (Article 7). Law No. 13 of 2008 regulates more detail in the BPDAU whose task is to collect, manage, develop and account for the management of DAU (Article 48).

Law No. 13 of 2008 experienced changes regulated in Government Regulation in lieu of Law (PerPPU) No. 2 of 2009 concerning Amendments to Law No. $132008 .{ }^{17}$ PerPPU is stipulated as an adjustment to the obligations of Indonesian pilgrims to use ordinary passports starting at $1430 \mathrm{H}$. PerPPU No. 2 of 2009 subsequently determined to become Law No. 34 of 2009 concerning Establishment of Government Regulation in Lieu of Law No. 2 of 2009.

Financial management of the pilgrimage has evolved with the enactment of Law no. 34 of 2014 concerning Financial Management of Hajj. ${ }^{18}$ The law

\footnotetext{
${ }^{13} \mathrm{Al}-$ Sayyid Sābiq, Fiqh Al-Sunnah (Kairo: Al-Fatḥ li al-I'lām al-'Arabī, n.d.). 440.

14 Muștafā Al-Khīn, Muștafā Al-Bughā, 'Alī al-Sharjabī, Al-Fiqh Al-Manhaj̄̄ 'Alā Madhhab Al-Imām Al-Shāfí̀ìiz3.

15‘Law No. 17 of 1999.

${ }^{16}$ Law No. 13 of 2008.

17'PerPPU No 2 Tahun 2009.

18'Law No. 34 of 2014.
} 
mandates the establishment of BPKH. The technical formation of BPKH membership is regulated in Government Regulations (PP) No. 76 of 2016 concerning Procedures for Election, Proposal, and Determination of Members of the Implementing Body and Members of the Supervisory Board as well as Prospective Replacement Members between the Time of the Implementing Agency Members and BPKH Supervisory Board Members. While the technical implementation of Law no. 34 of 2014 regulated in PP No. 5 of 2018 concerning the Implementation of Law Number 34 of 2014 concerning Hajj Financial Management. ${ }^{19}$

Based on PP No. 5 of 2018, BPKH is an institution that manages the financial pilgrimage (Article 1). The purpose of the establishment of BPKH is to improve the quality of the implementation of the pilgrimage, increase the rationality and efficiency of the use of BPIH and increase the benefits for the benefit of Muslims (Article 3). BPKH has the duty to manage hajj finances including income, expenses and wealth (Article 7). Revenues consist of: deposits from special BPIH or BPIH, the value of the financial benefits of the pilgrimage, funds for the efficiency of the implementation of the pilgrimage, DAU and other sources that are legal and not binding (Article 8). Expenditures consist of: the implementation of the hajj pilgrimage, BPKH operations, placement and investment, returning BPIH deposits or Special BPIH, payment of the BPIH Special deposit balance to PIHK, payment of the benefit value of the BPIH deposit or Special BPIH, benefit activities for Muslims and return the difference in BPIH deposit balances or Special BPIH from stipulation of BPIH or Special BPIH of the current year (Article 19). Wealth consists of: money and goods that can be valued in money (Article 40).

The task of BPKH financial management must be in line with the principles of sharia asset management. Sharia asset management principles consist of producing, developing, protecting, purifying and distributing assets. ${ }^{20}$ The process of producing wealth in Islam is regulated so that it is protected from the haram (ribā, gharar or maysir). Firdaus states that in order to obtain blessings, humans must first meet the needs of religion, soul, reason and posterity. If it

\footnotetext{
${ }^{19 `}$ Government Regulation No. 5 of 2018.

${ }^{20}$ Shafii, Yusoff, and Noh, Islamic Financial Planning and Wealth Management.
} 
does not go through the cycle, the assets obtained are indicated to have no blessing. 21

Buang explained that Islam allows 3 ways to get wealth. First; ihyā' almawāt, namely obtaining property by opening land to dead land and has never been planted so that it can provide benefits for shelter, farming and so on. Second; al-sayd is hunting animals or by fishing. Third; Ghanimah is obtained from war reparations. ${ }^{22}$

The process of developing assets is very important in the management of Islamic assets. Wealth is dynamic, Firdaus mentions the term assets are reversible. ${ }^{23}$ Wealth can develop but can return to the starting position and even go to a lower position than before. Wealth must be developed, it should not be kept idle. The process of developing assets is done by saving, business and investment in line with sharia. ${ }^{24}$ Therefore, risk management in developing assets is important to consider.

The process of protecting property is carried out with a takaful scheme. The scheme aims to reduce the risk of loss or disaster. ${ }^{25}$ Tabarru'-based takaful (funds to help). Takaful is a process of mutual assistance between group members with the aim of virtue. Risks that occur to one member are borne jointly.

The process of spending wealth should be as needed. Islam forbids spending wealth aimed at showing off wealth and luxury. Wasteful can be considered as an act of not being grateful for God's grace.

The process of purifying property becomes a differentiator between management of sharia and non-sharia assets. Islam views that purification of wealth is not purifying property obtained through haram. It is not possible to clean the body by using soap that has been dirty or germ, ${ }^{26}$ but by removing some of the assets obtained (zakat). Zakat has a function as a variable of

\footnotetext{
${ }^{21}$ Achmad Firdaus, Maslahah Performa: Sistem Kinerja untuk Mewujudkan Organisasi Berkemaslahatan(Yogyakarta: Deepublish, 2014).

${ }^{22}$ Ahmad Hidayat Buang, 'Appreciation Of Syari'ah Principles In Property Management In Contemporary Malaysia Society', Shariah Journal 16 (2008): 555-66.

23Firdaus, Maslahah Performa: Sistem Kinerja untuk Mewujudkan Organisasi Berkemaslahatan.

${ }^{24}$ Nurizal Ismail, Maqashid Syariah dalam Ekonomi Islam (Yogyakarta: Smart WR, 2014). 101.

25Ismail, Maqashid Syariah dalam Ekonomi Islam., 101

26Firdaus, Maslahah Performa: Sistem Kinerja untuk Mewujudkan Organisasi Berkemaslahatan.
} 
economic justice with a clear division of așnäf. Ismail explains the purpose of zakat, ${ }^{27}$ which is to clean income and give part of the property to those who are entitled. The means of purifying property other than zakat are also carried out with alms, donations or other social donations. ${ }^{28}$

The process of distributing assets is sometimes done when someone dies. Distribution of assets in the non-sharia system is prioritized to pay debts or taxes. Property is distributed according to a court decision based on a will that has been made or decided by law. But in Islam, after deducting debt, taxes and alms, wealth is distributed according to farāitid.

Table 1. Operationalization of the Hajj Financial Management Conformity Variable in Management of Sharia Assets

\begin{tabular}{|c|c|c|c|}
\hline No & Variable & Description & $\begin{array}{l}\text { Research } \\
\text { Development }\end{array}$ \\
\hline \multirow[t]{2}{*}{1} & $\begin{array}{l}\text { Produce } \\
\text { treasure }\end{array}$ & $\begin{array}{l}\text { BPKH process in } \\
\text { collecting hajj funds. }\end{array}$ & $\begin{array}{l}\text { BPKH policy in determining } \\
\text { the amount of BPIH }\end{array}$ \\
\hline & See footnote. ${ }^{29}$ & & \\
\hline \multirow[t]{2}{*}{2} & $\begin{array}{l}\text { Developing } \\
\text { wealth }\end{array}$ & $\begin{array}{l}\text { BPKH process in } \\
\text { developing hajj } \\
\text { funds. }\end{array}$ & $\begin{array}{l}\text { BPKH policy in: } \\
\text { - Determine the investment } \\
\text { mechanism for Hajj funds } \\
\text { - Choosing investment } \\
\text { instruments according to } \\
\text { sharia. }\end{array}$ \\
\hline & See footnote. ${ }^{30}$ & & \\
\hline 3 & $\begin{array}{l}\text { Protect } \\
\text { property }\end{array}$ & $\begin{array}{l}\text { BPKH process in } \\
\text { maintaining funds } \\
\text { from various risks of } \\
\text { investment losses or } \\
\text { other disasters. }\end{array}$ & $\begin{array}{l}\text { BPKH policy in: } \\
\text { - } \quad \text { Providing solutions in risk } \\
\text { mitigation } \\
\text { - Overcoming problems } \\
\text { when disasters occur on } \\
\text { prospective pilgrims. }\end{array}$ \\
\hline
\end{tabular}

27Ismail, Maqashid Syariah dalam Ekonomi Islam. 102.

${ }^{28}$ Atika Rukminastiti Masrifah and Achmad Firdaus, "The Framework Of Maslahah Performa as Wealth Management System and Its Implication for Public Policy Objectives', Media Syariah 18, no. 2 (2016).

${ }^{29}$ Zurina Shafii, Zarinah Yusoff, and Shahizan Md Noh, Islamic Financial Planning and Wealth Management (Kuala Lumpur: IBFIM, 2013), 16. Firdaus, Maslahah Performa: Sistem Kinerja Untuk Mewujudkan Organisasi Berkemaslahatan,, 172 Ismail, Maqashid Syariah Dalam Ekonomi Islam; Undang-Undang No 13 Tahun 2008; Undang-Undang No. 34 Tahun 2014; PPNo.5 Tahun 2018.

${ }^{30}$ Ismail, Maqashid Syariah dalam Ekonomi Islam, 102; Shafii, Yusoff, and Noh, Islamic Financial Planning and Wealth Management, 16; Undang-Undang No. 34 Tahun 2014; PP No.5 Tahun 2018. 


\begin{tabular}{|c|c|c|c|}
\hline & See footnote. ${ }^{31}$ & & \\
\hline \multirow[t]{2}{*}{4} & $\begin{array}{l}\text { Purifying } \\
\text { property }\end{array}$ & $\begin{array}{l}\text { The BPKH process in } \\
\text { purifying the } \\
\text { investment returns } \\
\text { of the hajj funds and } \\
\text { giving a portion to } \\
\text { those who are } \\
\text { entitled }\end{array}$ & $\begin{array}{l}\text { BPKH policy in: } \\
\text { - Clean the investment } \\
\text { returns on the pilgrimage } \\
\text { fund } \\
\text { - Give a portion of the profits } \\
\text { to Mustahik }\end{array}$ \\
\hline & See footnote. ${ }^{32}$ & & \\
\hline 5 & $\begin{array}{l}\text { Distributing } \\
\text { assets }\end{array}$ & $\begin{array}{l}\text { The BPKH process in } \\
\text { utilizing haj funds to } \\
\text { create prosperity for } \\
\text { pilgrims or for the } \\
\text { community }\end{array}$ & $\begin{array}{l}\text { BPKH policy in: } \\
\text { - Distributing the results of } \\
\text { financial management of } \\
\text { the pilgrimage. }\end{array}$ \\
\hline
\end{tabular}

\section{Alignment of BPKH Hajj Financial Management Policies to Sharia Purposes (Maqāṣid al-Sharīah)}

The position of sharia application in the management of hajj funds in PP No. 5 of 2018 is very prominent. Among these are the use of haj funds management accounts at Islamic banks (Article 1). ${ }^{34}$ Hajj financial placement is carried out in sharia banking products (Article 26). Hajj financial investment is carried out according to sharia principles by considering aspects of security, prudence, value of benefits, and liquidity (Article 26). ${ }^{35}$ The recommended sharia investment is in the form of sharia securities (Article 28). ${ }^{36}$ Hajj Financial

\footnotetext{
${ }^{31}$ Ismail, Maqashid Syariah dalam Ekonomi Islam, 102; Shafii, Yusoff, and Noh, Islamic Financial Planning and Wealth Management, Undang-UndangNo. 34 Tahun 2014; PPNo.5 Tahun 2018.

${ }^{32}$ Ismail, Maqashid Syariah Dalam Ekonomi Islam, Shafii, Yusoff, and Noh, Islamic Financial Planning and Wealth Management, Masrifah and Firdaus, "The Framework Of Maslahah Performa as Wealth Management System and Its Implication for Public Policy Objectives'; Law No. 34 of 2014; Government Regulation No. 5 of 2018.

33IPHI, 'Pelaksanaan Haji Indonesia', in Forum 'Ijjtima' Ulama Komisi Fatwa Se-Indonesia IV' MUI 2012, 2012, 1-14; Ismail, Maqashid Syariah Dalam Ekonomi Islam, Shafii, Yusoff, and Noh, Islamic Financial Planning and Wealth Management; Law No. 34 of 2014; Government Regulation No. 5 of 2018.

${ }^{34}$ Government Regulation No. 5 of 2018 . Article 1.

${ }^{35}$ Government Regulation No. 5 of 2018. Article 26.

${ }^{36}$ Government Regulation No. 5 of 2018. Article 28.
} 
Investment in the form of gold accounts is managed by Islamic financial institutions (Article 29). ${ }^{37}$

BPKH has the principle of prudence in the management of hajj finances that is done carefully, thoroughly, safely and in an orderly manner and considers aspects of financial risk. The principle of benefit is the financial management of the pilgrimage must provide benefits for pilgrims and Muslims. The principle of non-profit is the management of financial pilgrimage is done by prioritizing the use of the results of the development of funds that provide benefits for pilgrims and the benefit of Muslims with no distribution of dividends for management. The transparent principle, namely the management of hajj finances is conducted openly and honestly through the provision of information to the public, especially to pilgrims about the implementation and results of hajj financial management. The principle of accountability, namely the management of hajj finances is carried out accurately and can be accountable to the public, especially to pilgrims. (Explanation of Law No. 34 of 2014). ${ }^{38}$

The principle of BPKH which is based on prudence, meticulous, thorough, safe, orderly, liquidity, consideration of aspects of risk, benefit, efficiency, effectiveness, transparent, accountable, is a mirror of the application of sharia values. The application of sharia values to financial management is intended to achieve sharia objectives (maqāṣid al-sharīah). Maqāṣid al-sharī'ah appears from the protection activities of five main things (al-kulliyyah al-khamsah) those are protection of religion, soul, reason, descent and wealth. ${ }^{39}$

Maqāṣid al-sharī'ah is a compound sentence form (tarkïb iḍāfi) from the words maqāșid and sharīah. Maqāṣid is derived from the word qașada which means to mean or intend. ${ }^{40}$ Meanwhile, according to Ibn 'Ashūr, maqāṣid in terms of shara' are actions and actions intended for the substance (actions and actions) as human instincts, desiring to achieve them with various efforts and instincts without coercion in doing so. ${ }^{41}$

\footnotetext{
${ }^{37}$ Government Regulation No. 5 of 2018 . Article 29.

38Law No. 34 of 2014.

${ }^{39}$ Masrifah and Firdaus, "The Framework Of Maslahah Performa as Wealth Management System and Its Implication for Public Policy Objectives'.

40Munawwir and Fairuz, Kamus Al-Munawwir Indonesia-Arab Terlengkap.1123.

${ }^{41}$ Muhammad Ṭāhir Ibn 'Ashūr, Maqāṣid Al-Sharīah Al-Islāmiyyah (Qatar: al-Syaikh Muhammad bin Khalifah al-Asanī, 2004), 415.
} 
Shari'ah in language comes from the word shara'a which means making rules. ${ }^{42} \mathrm{Abu}$ Zahrah states that the existence of Islamic sharia is a blessing for humans. Allah says: "We did not send You, O Muhammad, but as a mercy to all humanity" (Al-Anbiyā 21: 107). Allah says: "O people, verily you have come to learn from your Lord and healer for diseases in the chest and guidance and mercy for those who believe" (Yūnus 10: 57).43

Ibn 'Ashür states that the general goal of sharia is to maintain the rules of the people, continue the continuity of goodness, both for humans, reason, work and something that appears on earth. ${ }^{44}$ Meanwhile, according to Al-Fāsī the goal of sharia in general is to prosper the earth, maintain the rules of life, establish goodness according to its place and uphold what has been charged fairly, istiqāmah, containing good for reason and work, improving and realizing good things and be able to regulate the benefits for many people. 45

Whereas the purpose of sharia in particular is the state intended by al-Shāri' to realize human objectives that are beneficial or maintain the general prosperity in special rules. So the effort to achieve special benefit does not cancel public wealth, because of negligence or following the passions. ${ }^{46}$ Meanwhile, according to Abu Zahrah Islamic Sharia laws have three objectives those are tahdhïb al-fard (education for individuals), iqāmah al-'adl (upholding justice) and mașlaḥa. ${ }^{47}$

Thus, maqāsid al-sharì'ah is the goal, wisdom or secret of the establishment of a sharia law. Maqāșid al-sharīah aims to guarantee the benefits of humanity (jalb al-mașālih) and protect humanity from damage and evil (daf'al-ḍarr) both in the life of the world and the hereafter and aims to achieve justice. Protection of human beings is related to mașlaha. Mașlaha is divided into three levels, namely ḍarūriyāt (primary), hạjjïiyāt (secondary) and taḥsiniyāt or kamāliyāt

\footnotetext{
42Munawwir and Fairuz, Kamus Al-Munawwir Indonesia-Arab Terlengkap. 711.

43Muhammad Abū Zahrah, Ușūl Al-Fiqu (Kairo: Dār al-Fikr al-'Arabī, n.d.), 346-366.

${ }^{44}$ Muḥammad Țāhir Ibn 'Ashūr, Maqāṣid Al-Sharīah Al-Islämiyyah (Qatar: al-Syaikh Muhammad bin Khaliffah al-Asanī, 2004), 273.

45‘Alal Al-Fāsī, Maqāṣid Al-Sharīah Al-Islāmiyyah Wa Makārimuhā,5th ed. (Rabat: Dār al-Gharb alIslāmī, 1993). 45-46.

46 Ibn 'Ashūr, Maqāṣid Al-Sharīah Al-Islāmiyyah, 415.

47Zahrah, Ușül Al-Fiqh. 364-366.
} 
(supplementary). Mașlaḥa ḥäjjiyāt and tahsinniyyāt could not be realized if the Mașlaḥa ḍarūriyāt was not fulfilled. ${ }^{48}$

Maslaha ḍaruriyāt refers to the maintenance of five things (maqāșid alkhamsah) namely the maintenance of religion, soul, wealth, intellect and descent. ${ }^{49}$ Abū Zahrah mentions that if the five things are not maintained then the noble human life will also not be able to be maintained perfectly. In essence the world as a place of human life, is based on the five pillars of life.

Maqāșid al-khamsah is placed in the position of darūriyāt because it is the most powerful level of mașlaha..$^{0}$ The maintenance of religion shows that the role of religion is very important. Maintenance of the soul, mind and offspring is maintenance related to humans individually. All three are related to the needs of human life, namely physical, psychological, educational, health and survival needs. Maintenance of assets is any action taken in managing assets. ${ }^{51}$

Table 2. Operationalization of Hajj Financial Management Policy Alignment Variables with Sharia Objectives (Maqāșid al-sharīah)

\begin{tabular}{|c|c|c|c|}
\hline No & Variabel & Deskripsi & Pengembangan Instrumen Penelitian \\
\hline \multirow[t]{2}{*}{1} & Hifz Din & $\begin{array}{l}\text { BPKH policy can } \\
\text { increase the faith and } \\
\text { maintain the religion } \\
\text { of the pilgrims. }\end{array}$ & $\begin{array}{l}\text { The level of importance and certainty } \\
\text { of BPKH's policy node in: } \\
\text { - Paying attention to the conditions } \\
\text { of istițā'ah, manasik and manafi } \\
\text { 'pilgrimage in maintaining the } \\
\text { pilgrimage kemabruran } \\
\text { - Managing hajj finances } \\
\text { professionally, transparently, } \\
\text { accountably, productively and in } \\
\text { accordance with sharia principles. }\end{array}$ \\
\hline & & & \\
\hline 2 & $\begin{array}{l}\text { Hifz } \\
\text { Nafs }\end{array}$ & $\begin{array}{l}\text { BPKH policy must be } \\
\text { able to maintain the } \\
\text { health of pilgrims and } \\
\text { keep diseases, both }\end{array}$ & $\begin{array}{l}\text { The level of importance and certainty } \\
\text { of BPKH's policy node in: } \\
\text { - The concept of accommodation and } \\
\text { accommodation for pilgrims. }\end{array}$ \\
\hline
\end{tabular}

${ }^{48}$ Abū Hāāmid Muhammad ibn Muhammad Al-Ghazāili, Al-Mustashfā Min Ilm Al Ushūl (Beirut: Dar Ihyā at-Turāts al-Ārabi, n.d.); Muḥammad Abū Zahrah, Ușūl Al-Fiqh, 174.

${ }^{49}$ Abū Zahrah, Ușūl Al-Fiqh, 366-367.

${ }^{50}$ Abū Zahrah, Ușūl Al-Fiqh, 554.

51Ismail, Maqashid Syariah dalam Ekonomi Islam. 65.

52Ismail; IPHI, 'Pelaksanaan Haji Indonesia'; Law No. 34 of 2014; Government Regulation No. 5 of 2018. 


\begin{tabular}{|c|c|c|c|}
\hline & & $\begin{array}{l}\text { impacting and not } \\
\text { impacting death. }\end{array}$ & $\begin{array}{l}\text { - Implementation of post-hajj } \\
\text { guidance by the Ministry of } \\
\text { Religion as regulator }\end{array}$ \\
\hline & \multicolumn{3}{|l|}{ Source: 53} \\
\hline \multirow[t]{2}{*}{3} & Hifz 'AqI & $\begin{array}{l}\text { The BPKH policy must } \\
\text { be able to safeguard } \\
\text { the need for education } \\
\text { as a factor in the } \\
\text { success of the world } \\
\text { and the hereafter. }\end{array}$ & $\begin{array}{l}\text { The level of importance and certainty } \\
\text { of BPKH's policy node in: } \\
\text { - Cooperation with the Ministry of } \\
\text { Religion in intensifying the Hajj } \\
\text { rituals so that pilgrims are better } \\
\text { prepared physically and mentally. }\end{array}$ \\
\hline & \multicolumn{3}{|l|}{ Source: 54} \\
\hline 4 & $\begin{array}{l}\text { Hifz } \\
\text { Maal }\end{array}$ & $\begin{array}{l}\text { BPKH policies must be } \\
\text { able to obtain funds in } \\
\text { a legal and clean way } \\
\text { from gharar, maysir, } \\
\text { tadlis, ihtikar and } \\
\text { usury. }\end{array}$ & $\begin{array}{l}\text { The level of importance and certainty } \\
\text { of BPKH's policy node in: } \\
\text { - The contract for hajj pilgrims and } \\
\text { BPKH is done with the yad } \\
\text { dhamanah wadi'ah contract, } \\
\text { replacing the pilgrimage bailout } \\
\text { funded in qardh }\end{array}$ \\
\hline & Source: 55 & & \\
\hline
\end{tabular}

\section{Suitability of BPKH Hajj Financial Management to Sharia Treasure Management}

\section{Produce wealth}

BPKH collects assets through BPIH and Special BPIH, which is a number of funds paid by citizens who will perform the hajj and special hajj pilgrimage. 56 The amount of BPIH is determined in PP after being approved by the DPR through the proposal of the Minister of Religion..$^{77}$ While the amount of initial deposit for pilgrims is determined by the Minister of Religion. ${ }^{58}$

The mechanism of Hajj registration through BPS BPIH, namely Islamic banking, both Islamic commercial banks or Islamic business units designated by

\footnotetext{
${ }^{53}$ Ismail, Maqashid Syariah dalam Ekonomi Islam, IPHI, 'Pelaksanaan Haji Indonesia'; UndangUndang No. 34 Tahun 2014; PP No.5 Tahun 2018.

${ }^{54}$ Ismail, Maqashid Syariah dalam Ekonomi Islam, IPHI, 'Pelaksanaan Haji Indonesia'; UndangUndang No. 34 Tahun 2014; PP No.5 Tahun 2018.

55Ismail, Maqashid Syariah dalam Ekonomi Islam, Undang-Undang No. 34 Tahun 2014; PP No.5 Tahun 2018.

${ }^{56}$ Law No. 34 of 2014. Article 1.

57Law No. 13 of 2008. Article 21.

${ }^{58}$ Government Regulation (PP) No. 5 of 2018.
} 
BPKH. ${ }^{59}$ Sulistyowati states that during the 2014-2018 Ministry of Religion has appointed seventeen Sharia banks, namely six sharia commercial banks and eleven sharia business units for regular BPIH BPS, eight banks have foreign exchange services for BPS BPIH specifically, transito banks (conventional banks) for regions that have no Islamic bank at all.60

Establishment of Islamic banks as BPS is a form of maintaining the property rights. ${ }^{61}$ The stipulation of sharia banks as BPS is also a representative of Islamic principles that are either complete or comprehensive. ${ }^{62}$

Special BPIH/BPIH deposits are paid into an account in the name of BPKH in its position as the legal representative of hajj pilgrims on hajj cash via BPS BPIH. ${ }^{3}$ The contract used is wakalah. DSN Fatwa No. 122 of 2018 states that the contract of attorney from prospective pilgrims to the government (BPKH) to do the work in accordance with the authorized object.

In practice, several banks impose different contracts. ${ }^{64}$ Bank Muamalat uses the wadi'ah contract for the pilgrimage. Whereas BSM uses a wakalah contract and a placement agreement with a mudharabah muthlaqah contract. While BNI Syariah uses 2 types of contracts, namely wadi'ah or mudarabah. This shows that BPS innovates the wakalah and mudarabah contracts in managing the initial deposit funds.

Every contract made by BPS should be adjusted to the conditions set by the government. The contract was published to all pilgrims who wanted to register the pilgrimage. Bunyamin emphasized that the idealistic first action in managing the Hajj deposit funds in accordance with sharia asset management is to review the contracts used at the beginning of the transaction. ${ }^{65}$ If the contract used is correct, the stages of developing, protecting and distributing hajj funds will be easier.

\footnotetext{
${ }^{59}$ Law No. 34 of 2014. Article 1.

${ }^{60}$ Interview with Sulistyowati, 2016.

${ }^{61}$ Shafii, Yusoff, and Noh, Islamic Financial Planning and Wealth Management, Ismail, Maqashid Syariah Dalam Ekonomi Islam, Firdaus, Maslahah Performa: Sistem Kinerja Untuk Mewujudkan Organisasi Berkemaslahatan.

${ }^{62}$ Law No. 34 of 2014. Elucidation of Article 2.

${ }^{63} \mathrm{Law}$ No. 34 of 2014.

${ }^{64}$ Interview with Sulistyowati, 2016.

65Interview with Bunyamin, 2016.
} 
Special BPIH/BPIH deposits belong to pilgrims who are deposited with the BPKH. However, the special BPIH/BPIH deposit balance cannot be taken by pilgrims until the completion of the pilgrimage. Retrieval of BPIH and/or Special BPIH deposits can only be made if the pilgrims cancel their portions, either due to death or other valid reasons. ${ }^{66}$ This is in line with DSN Fatwa No. 122 of 2018 which states that BPIH and Special BPIH funds are funds owned by prospective pilgrims on an individual basis.

The source of producing BPKH assets other than BPIH is DAU.67 DAU is the total amount of BPIH and BPIH efficiency results. As for Article 1 of Law No. 13 No. 2008 it is stated that DAU is the amount of funds obtained from the development of DAU and/or the remaining operational costs of organizing the Hajj and other halal and non-binding sources.

In order to make DAU management more effective for the benefit of Muslims, the government has formed the DAU Management Agency (BPDAU). Article 48 states that the main task of BPDAU is to collect, manage, develop and account for the DAU.

The function of BPDAU is to collect and develop DAU in accordance with sharia and statutory provisions, plan, organize, manage, and utilize DAU, and report the management of DAU to the President and Parliament. Article 1 of Law No. 342014 states that DAU is a number of funds which prior to the enactment of Law No. 342014 were obtained from the development of DAU and/or the remaining operational costs of organizing the hajj pilgrimage and other halal and non-binding sources in accordance with statutory provisions. Since 2005 the DAU has been frozen and not distributed in accordance with the designation under the Act. 68

\section{Developing wealth}

BPKH determines the investment mechanism for hajj funds and chooses investment instruments that are relevant to the authority. BPIH deposits should be written for productive matters and managed with risk mitigation. BPKH

\footnotetext{
66Law No. 34 of 2014. Article 6.

67Law No. 34 of 2014. Article 5.

68Interview with Suratman, 2016.
} 
places and invests Hajj finance according to sharia principles, prudence, security, and value of benefits. 69

$\mathrm{BPKH}$ is the legal representative of hajj pilgrims to manage Hajj funds through deposits of BPIH and Special BPIH paid to accounts in the name of BPKH.70 Objects authorized (mahal al-wakalah) to BPKH must be clear and certain, including among others: Development of BPIH funds and Special BPIH through placement and limited investment (al-muqayyadah) with investment activities that are in accordance with sharia principles, prudential principles, and security; Distribution of investment proceeds to prospective pilgrims; Payment of the implementation of the pilgrimage; Return of excess funds in the accounts of prospective pilgrims; Returns all BPIH or Special BPIH funds in the event that a prospective pilgrim dies or cancels departure. ${ }^{71}$

$\mathrm{BPKH}$ is permitted to convert hajj funds to halal sectors, namely sectors that avoid maysìr, gharar, ribā, zalim and other prohibitions. ${ }^{72}$ Letting pilgrimage funds settle (idle) in government accounts is not considered wise and good deeds. The results of the development of the hajj fund or the value of benefits become a source of revenue from BPKH.73 Investment instruments allowed by Law No. 342014 are in the form of banking products, securities, gold, direct investments and other investments. ${ }^{74}$

According to Agoga,75 before the BPKH was formed, the hajj fund investment instrument was still referring to government regulation Law No. 13 2008. Limited to three investment instruments, they are current accounts, deposits and national sharia letters (SBSN). In this case the Ministry of Religion gives priority to the placement of hajj funds in SBSN sukuk state which is safe and long-term. Suratman added that this actually became an obstacle for the

\footnotetext{
${ }^{69}$ Law No. 34 of 2014 . Article 24.

70Law No. 34 of 2014 . Article 6.

71DSN-MUI, 'Fatwa DSN-MUI No.122/DSN-MUI/II/2018 Tentang Pengelolaan Dana BPIH dan BPIH Khusus Berdasarkan Prinsip Syariah', Pub. L. No. 122/DSN-MUI/II/2018, 1 (2018).

72Ismail, Maqashid Syariah dalam Ekonomi Islam, 101; Shafii, Yusoff, and Noh, Islamic Financial Planning and Wealth Management, 172; Firdaus, Maslahah Performa: Sistem Kinerja untuk Mewujudkan Organisasi Berkemaslahatan; Masrifah and Firdaus, "The Framework Of Maslahah Performa as Wealth Management System and Its Implication for Public Policy Objectives'.

73Law No. 34 of 2014. Article 5.

${ }^{74}$ Law No. 34 of 2014 . Article 48.

75Interview with Agoga, 2016.
} 
Ministry of Religion due to limitations in the management and development of hajj funds in Indonesia. 76

\section{Protect property}

BPKH and BPS have an important role. Both institutions must be able to protect the funds of prospective pilgrims. Property management by BPKH and BPS relatively poses a liquidity risk if it is not managed properly. BPKH protects assets by guarding hajj funds against various risks in the form of investment losses or other risks.

Risk mitigation by BPS, according to Sulistyowati,77 is by raising the equivalent rate that is higher than the BI rate. This aims to attract BPKH's attention to keep funds in bank deposits. Suratman responded to the solution by proposing a new policy, namely the distribution of the proportion of hajj funds invested in sukuk and bank deposits. It is hoped that liquidity risk will not occur in the future. ${ }^{78}$

BPS as the manager of the hajj funds must ensure the safety of hajj funds. The government has ensured the guarantee of depositing hajj funds to banks through LPS. LPS is an institution that has the function of guaranteeing customer deposits. LPS is actively involved in maintaining the stability of the banking system in accordance with its authority (Chapter 3 Article 4 of Law No. 24 2004). Customer deposit guarantee at an Islamic bank has obtained MUI DSN provisions as Fatwa No. 118/DSN-MUI/II/2018.79

BPKH mitigates risks with the takaful scheme (MUI Fatwa DSN No. 39 2002). Some important things in the DSN fatwa include; Takaful Hajj has a tabarru' (grants) agreement that aims to help pilgrims fellow who are affected by the disaster; The contract was made between pilgrims as the giver of tabarru' and takaful who acted as the manager of the grant funds. BPKH as a representative of pilgrims acts as the parent policyholder of all pilgrims. Takaful contributions by pilgrims are already included in the BPIH payment component. If there is a risk for pilgrims, takaful is obliged to pay claims to pilgrims as takaful participants based on the agreement agreed at the beginning of the agreement.

\footnotetext{
76Interview with Suratman, 2016.

77Interview with Sulistyowati, 2016.

78Interview with Suratman, 2016.

${ }^{79}$ DSN-MUI, Fatwa DSN-MUI No.122/DSN-MUI/II/2018 Tentang Pengelolaan Dana BPIH dan BPIH Khusus Berdasarkan Prinsip Syariah.
} 
If an operational surplus occurs, pilgrims are entitled to get the surplus. Management of operational surpluses is mandated by BPKH as the holder of a Parent policy for the benefit of the people.

In Law No. 13 2008, Law No. 342014 and PP No 52018 did not mention risk mitigation for prospective pilgrims through the takaful scheme. Considering the importance of protecting against risks received by prospective pilgrims, it is necessary to regulate the technical provisions regarding risk mitigation with takaful schemes. ${ }^{80}$

\section{Purifying property}

The process of purifying property through zakat payment should be carried out by BPKH. However, when examined in Law No. 34 of 2014 or in PP No 5 of 2018, there is no obligation to pay zakat. In Article 19 PP No. 5 of 2018 it is stated that what is meant by expenditure are a. Organization of Hajj; b. BPKH operations; c. Hajj financial placement and/or investment; d. Return of deposits BPIH and/or BPIH Special pilgrims who cancel the departure with a valid reason; e. Payment of Special BPIH deposit balance to PIHK; f. Payment of BPIH deposit and/or Special BPIH benefit value; g. Activities for the benefit of Muslims; and $\mathrm{h}$. Returns the difference between the balance of the BPIH deposit and/or the Special BPIH from the determination of the current BPIH and/or BPIH.

This is different from the Tabung Haji Malaysia (THM). THM pays zakat on behalf of prospective pilgrims. Therefore, prospective pilgrims do not need to pay zakat anymore. This is in line with Malaysia's 17th Fatwa Committee of the National Council for Islamic Religious Affairs on 3 May 1979.

When prospective pilgrims register Hajj, he pays BPIH deposits to the BPKH account at BPS. There was a contract between him and BPKH. He will receive the services of organizing the Hajj according to the portion number of the Hajj departure. Therefore, there is also an obligation to manage Hajj funds and Hajj implementation services by BPKH. So that the obligation to pay zakat lies with $\mathrm{BPKH}$ not to the prospective pilgrims.

In Law No. 13 of 2008, Law No. 34 of 2014 and PP No 5 of 2018 did not mention the obligation to pay zakat for BPKH. Given the importance of the

\footnotetext{
80Firdaus, Maslahah Performa: Sistem Kinerja untuk Mewujudkan Organisasi Berkemaslahatan; Masrifah and Firdaus, "The Framework of Maslahah Performa as Wealth Management System and Its Implication for Public Policy Objectives'.
} 
obligation of zakat as a means to purify property, it is necessary to set technical provisions regarding the obligation of paying zakat for BPKH. 81

\section{Distributing assets}

BPKH utilizes hajj funds to create prosperity for pilgrims in particular and the community in general. Therefore, it is needed a BPKH policy in distributing the results of hajj financial management. Referring to Article 19 PP No. 5 of 2018, included in the distribution of assets by the BPKH is the cost of organizing the pilgrimage, operational BPKH, returning BPIH deposits and Special BPIH for pilgrims who cancel the departure due to death or other valid reasons, payment of the balance of the deposit Special BPIH to PIHK, payment of BPIH and/or Special BPIH deposit value benefits, activities for the benefit of Muslims, and returning the difference between BPIH and/or Special BPIH deposit balances from the determination of BPIH and/or Special BPIH for the current year.

Article 21 PP No. 5 of 2018 explains that the cost of organizing the pilgrimage comes from the balance of BPIH and Special BPIH from pilgrims who perform the pilgrimage in the current year and the acquisition of the value of benefits in the current year. BPIH is determined by the central government after obtaining approval from the DPR.

Expenditures for the benefit of Muslims come from the benefits of DAU (Article 38 PP No. 5 of 2018). BPKH determines the amount of DAU benefits based on the proportion of DAU to haj finance. The maximum benefit value of DAU is equal to the total value of DAU benefits from the previous year. BPKH sets priorities for activities and the amount of use of the DAU benefit value. In setting priorities for activities, BPKH coordinates with the Minister.

DAU can be empowered according to its designation. DAU must not be spent by spending, giving or donating, but the funds must be endowments like immovable waqf property, such as land and mosques. Therefore, the DAU needs to be invested in a business that is safe, has a low risk, generates periodic profits, so that the benefits of the development value may continue to flow.

\footnotetext{
${ }^{81}$ Achmad Firdaus and Nurizal Ismail, 'Using Maslahah Performa as an Islamic Wealth Management System', in Thematic Workshop on Al-Māl: Philosophy and Its Application in Islamic Perspective, UKM-IRTI, Institute of Islamic Training Malaysia (ILIM) (Selangor, 2014), 1-13; Firdaus, Maslahah Performa: Sistem Kinerja untuk Mewujudkan Organisasi Berkemaslahatan; Masrifah and Firdaus, "The Framework of Maslahah Performa as Wealth Management System and Its Implication for Public Policy Objectives'.
} 
Overall a number of factors influences the financial management of the hajj pilgrimage at $\mathrm{BPKH}$ to suit sharia asset management:

a. The contract factor between prospective pilgrims as BPIH owners and $\mathrm{BPKH}$ as hajj financial managers. The contract used must be in accordance with Islamic principles.

b. Zakat payment factor by BPKH and the participation of pilgrims in the takaful scheme that has not been regulated in Law No. 34 of 2014 nor PP No. 5 of 2018.

c. Transparency factor where BPKH as a hajj financial management institution must be transparent in managing pilgrims funds.

\section{Alignment of Hajj Financial Management Policies by BPKH towards Maqāṣid al-Shari'ah}

\section{Policy Node Ḥifẓ Dīn}

$\mathrm{BPKH}$ policy must be able to increase the faith of pilgrims. The results of the interview show the seven points of protection policy on religion. SAST analysis results get the 3 most important and definite policy nodes in religious safeguards, namely D4 (fair and transparent distribution of pilgrim quota arrangements), D2 (building facilities and infrastructure for hajj needed for operational haj)), and D1 (BPKH ensures istițä'ah requirements prospective pilgrims). The results of data processing are as shown in figure 3.

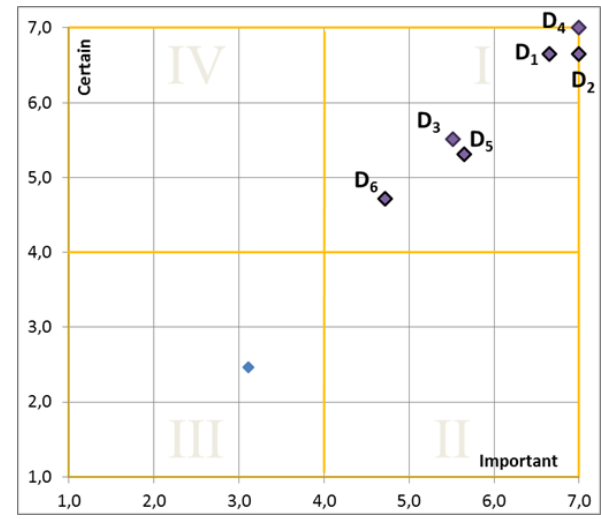

Figure 3. Policy Node Hifẓ Din

The policy node for the fair and transparent distribution of pilgrims quota distribution (D4) has a high degree of importance and certainty. This is because the waiting list for the pilgrimage is getting longer due to the registration which 
is opened continuously throughout the year. Indonesian Hajj Religion Association (IPHI) ${ }^{82}$ proposed a solution that was presented at the Ijtima' Ulama forum of the Indonesian Fatwa Commission IV MUI. A moratorium is needed for several years. It aims to reorganize a better registration system. At the same time the BPKH can determine the priority scale for the pilgrimage to prospective pilgrims in futile and regions that have a very long waiting list.

BPKH builds facilities and infrastructure for hajj needed for operational operations for hajj (D2). The implementation of the pilgrimage procession in Mecca and Medina is a national task involving various elements both in the country and with the Government of the Kingdom of Saudi Arabia. Some indicators that can be used as references in the assessment of the operation of the pilgrimage include accommodation, catering and transportation services. The activity is a fundamental need for pilgrims to support calm in performing the pilgrimage.

Based on the Hajj Implementation Evaluation Report, ${ }^{83}$ it was found that problems arising during the implementation of the pilgrimage including lodging services in Mecca have not met the eligibility standards in aspects of health, safety and comfort. Catering distribution services are not on time and with a monotonous menu, and do not meet the needs of elderly worshipers. Transportation services have not been able to reach all lodgings. In addition, there are still many technical obstacles in transportation services. Some problems have been resolved. Although there are still some notes to improve the quality of the implementation of the pilgrimage in the future.

The policy node ensures the istită'ah conditions for prospective pilgrims (D1). Hajj must be performed by every Muslim once in a lifetime for those who fulfill the requirements to be able (istițä'ah) both financially and physically also mentally independent ${ }^{84}$ Hajj is held in the city of Mecca with a large number of worshipers, coming from various countries with different behavior, customs, culture and languages. The pilgrimage is held at a certain time with a long duration of time.

\footnotetext{
82IPHI, 'Pelaksanaan Haji Indonesia'. 8. 44.

${ }^{83}$ Kementerian Agama Republik Indonesia, 'Laporan Evaluasi Penyelenggaraan Ibadah Haji 2013'.

${ }^{84}$ Wahbah Al-Zuhaylī, Al-Fiquh Al-Islāmī Wa Adillatuh, 2nd ed. (Damaskus: Dār al-Fikr al-'Arabī, 1985); Saî̀d 'Abd al-Qādir Bashnafar, Al-Mughnī Fì Fiqh Al-Haj Wa Al-'Umrah (Jeddah: Maktabah Al'Ilm, 1993).16.
} 


\section{Policy Node Hifz Nafs}

The results of the interview show ten points of life protection policy. The results of the SAST analysis obtained the four most important and definite policy nodes in life care, namely N8 (ensuring the use of vaccines that were declared halal by N2 (providing and funding Hajj guidance officers), ${ }^{85} \mathrm{~N} 3$ (improving the quality of catering, lodging, transportation and health services especially during implementation of the pilgrimage in Mecca and Medina) and N4 (submit data on prospective pilgrims in the current year earlier to the Ministry of Health).

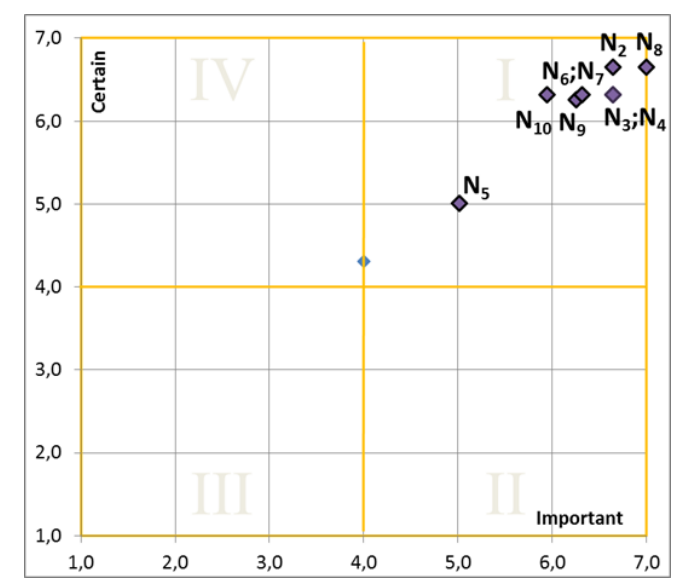

Figure 4. Policy Nodes Hifẓ Nafs

The policy node ensures that the use of vaccines declared as halal by MUI (N8) has a high level of importance and certainty. The halal vaccine reference has been established by MUI on fatwa No 06 of 2010. Fatwa aborts MUI fatwa No. 52009 which states that for people who perform Hajj/umrah may use illegal miningitis vaccine because of al-häjah (urgent need). BPKH is responsible for preventing the transmission of diseases that may be carried by pilgrims. Prevention of disease transmission becomes part of the implementation of hajj health.

In 2015 the spread of the MERS-CoV virus. The plague first infected the Saudi Arabian community in 2012. Saudi Arabia became the country with the most cases of MERS in the Middle East region. This shows that vaccine

85MUI, 'Fatwa MUI No 6 Tahun 2010’ (2010). 
management is very important. The health sector must be considered to ensure the prevention and early detection of the health of prospective pilgrims.

The policy node provides and funds the Hajj guidance officer (N2). Counseling and guidance of pilgrims is part of fostering the pilgrimage (Article 1 of Law No. 13 of 2008). ${ }^{86}$ Guidance, service and protection of pilgrims in carrying out the pilgrimage is a right for pilgrims. Guidance related to Hajj rituals and other material, both in the country, on trips, as well as in Saudi Arabia (Article 7 of Law No. 13 of 2008). ${ }^{87}$

The policy node enhances the quality of catering, accommodation, transportation and health services, especially during the implementation of the pilgrimage in Mecca and Medina (N3). Provision of transportation and lodging comfort while in the homeland, Arab Saudi, and when returning home is a mandate that must be fulfilled by the organizers of the pilgrimage. 88 The activities of organizing Hajj services must be based on the principles of justice, professionalism, and accountability. ${ }^{89}$

The policy node submitted data on prospective pilgrims in the current year earlier to the Ministry of Health (N4). Data on current pilgrimage candidates is very important for the integrated Haj computerization system in the health sector (Siskohatkes). Data useful for the management of the health of pilgrims. Health data greatly affect the conditions of pilgrimage istităa'ah. Data is also needed in controlling health risk factors for pilgrims during in Indonesia, traveling, and Saudi Arabia.

\section{Policy Node Ḥifz 'Aql}

The results of the interviews show that two protection policy nodes are common sense. However, the results of the SAST analysis show that there is one policy node that is most important and certain in safeguarding the mind A2 (improving the quality of rituals and the socialization of hajj).

The A2 policy node has a high degree of importance and certainty. This is caused by the high interest of the people to worship the pilgrimage has not been accompanied by knowledge of the pilgrimage as a whole. There are still many

\footnotetext{
${ }^{86}$ Law No. 13 of 2008. Article 13.

${ }^{87}$ Law No. 13 of 2008 . Article 7.

${ }^{88}$ Law No. 13 of 2008 . Article 7.

${ }^{89}$ Law No. 13 of 2008 . Article 2.
} 
worshipers who do not understand the perfection of the pilgrimage. For example, during the ihram condition, pilgrims stopped by the hotel lodgings and changed clothes with jackets, clothes, etc., even though tawaf and tahallul had not been implemented.

The implementation of the pilgrimage requires mastery of aspects of religious knowledge. Guidance for pilgrims needs to be increased, the frequency of guidance for pilgrims must be increased. Evaluation in 2015, guidance on hajj has not been maximized enough to give understanding to prospective pilgrims. At that time the allocation of ritual activities was returned to 10 times the guidance with details 7 times at the Office of Religious Affairs (KUA) and 3 times at the district/city level.

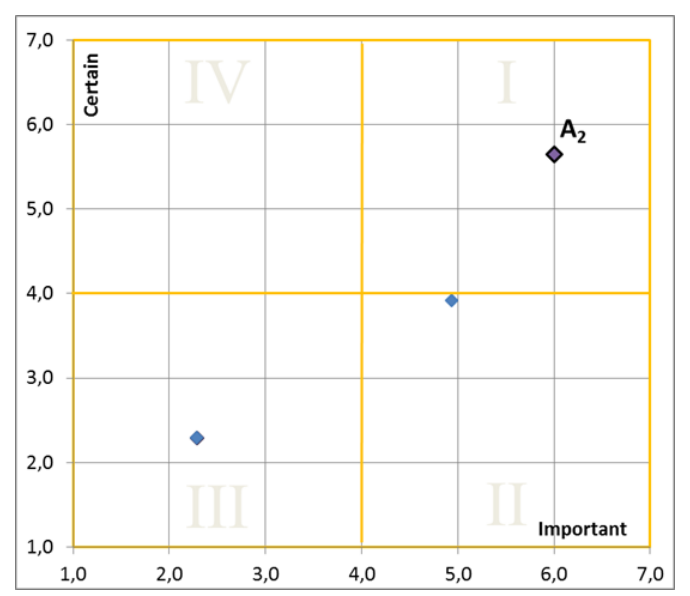

Figure 5. Policy Nodes Hifz 'Aql and Hifz Nasl

Recruitment of pilgrims also needs improvement. Coaching pilgrims begins with selective recruitment based on competencies that are done online, in order to avoid certain interests. Then the interview competency test is conducted with the substance of the implementation of the pilgrimage services. The expected goal is to obtain pilgrims who serve pilgrims in a professional and responsible manner. Since starting from departure until returning to the country.

\section{Policy Node Ḥifẓ Māl}

The results of the interview show the eight nodes of the policy to protect property. The results of the SAST analysis found the three most important and definite policy nodes namely M6 (Hajj fund management must be transparent), 
M4 (directing Hajj funds to direct investment with Sharia principles), and M3 (directing Hajj funds management in Sharia banking).

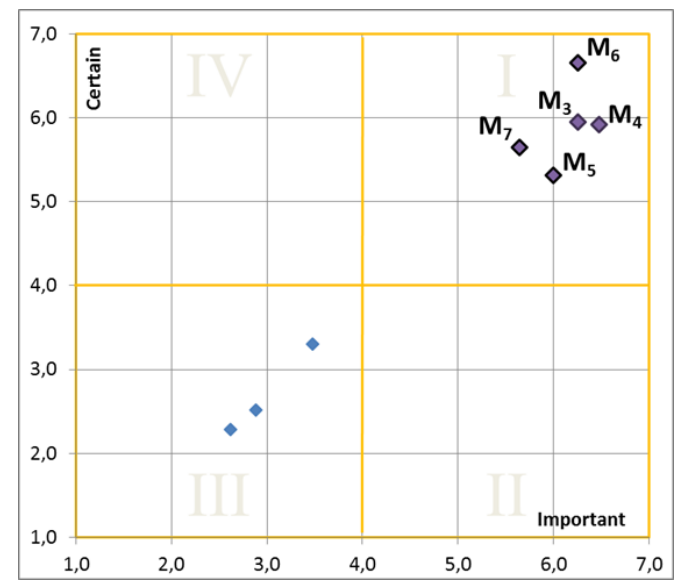

Figure 6. Node of Policy Hifz Māl

The policy node of the transparent Hajj financial management (M6) has a high degree of importance and certainty. This is the mandate of Law No. 34 of $2014 .{ }^{90}$ Transparency in hajj fund management increases public trust in the credibility of hajj financial management providers. Law No. 34 of 2014 mandates transparency by providing information through the media about financial performance and wealth, and development results on a regular basis every six months. Transparency to pilgrims about the benefits of BPIH and Special BPIH through the virtual account of each pilgrim. As an Islamic financial institution, BPKH must keep records in accordance with applicable accounting standards. Reports on the implementation of Hajj Financial management are conducted regularly every six months to the Minister and the Parliament.

The policy node directs the management of hajj funds to direct investment (M4). Hajj financial management is carried out in the form of investments whose benefits are used to improve the quality of the Hajj, rationality and efficiency of BPIH, as well as for the benefit of Muslims. UU no. 342014 mandates the management of financial pilgrimage with the principles of sharia, prudence, benefits, non-profit, transparent, and accountable. ${ }^{91}$ Direct investment in the

\footnotetext{
${ }^{90}$ Law No. 34 of 2014 . Article 2.

${ }^{91}$ Law No. 34 of 2014 . Article 2.
} 
real sector helps government programs in improving the economic welfare of the community, especially pilgrims. Referring to Article 30 PP No. 5 2018, direct investment is carried out by: owning a business, equity participation, investment cooperation, and other direct investment. Direct investment can be done in the form of cooperation with business entities or institutions both domestically and abroad. The portion of direct investment is at most twenty percent of the total hajj financial investment.92

The policy node directs the management of hajj funds to Islamic banking (M3). Islamic banking products that are permitted for hajj financial investments include: current accounts, time deposits and savings. Referring to PP No. 5 of 2018, for the three years since BPKH was formed, the placement of Islamic banking products was at most fifty percent of the total placements and investment of hajj finance. Furthermore, after three years the BPKH has been formed, the placement of Islamic banking products is at most thirty percent of the total hajj financial placements and investments. ${ }^{93}$

\section{Conclusion}

Important factors for the management of hajj funds by BPKH refer to the management of sharia assets are as follows.

1. The contract factor between prospective pilgrims as the owner of BPIH funds with BPKH as the Hajj financial manager. The contract used must be in accordance with Sharia principles.

2. Zakat payment factors by BPKH and the participation of pilgrims in the takaful scheme that have not been regulated in Law No. 34 of 2014 nor PP No. 5 of 2018. Required special rules for both.

The BPKH policy nodes which are in accordance with the maqașid alshari'ah are as follows.

1. Religious protection nodes: fair and transparent distribution of hajj pilgrims quota distribution, building hajj facilities and infrastructure needed for hajj operations, and BPKH ensures the conditions of hajj pilgrims.

2. Soul care nodes: ensuring the use of vaccines declared halal by MUI, providing and funding Hajj guidance officers, improving the quality of catering, lodging, transportation and health services especially during

\footnotetext{
${ }_{92}$ Government Regulation No. 5 of 2018. Pasal 30.

93‘'Government Regulation No. 5 of 2018 ' (n.d.).Pasal 27.
} 
the implementation of the pilgrimage in Mecca and Medina and submitting data on prospective pilgrims during the year of traveling earlier to the Ministry of Health.

3. Reason for guarding the mind: improving the quality of the rituals and the socialization of the pilgrimage

4. The asset guardian node: the management of hajj funds must be transparent, directing the management of hajj funds to direct investment with sharia principles and directing the management of hajj funds to Islamic banking.[a]

\section{BIBLIOGRAPHY}

'Ashūr, Muhammad Ṭāhir Ibn. Maqāṣid Al-Sharīah Al-Islāmiyyah. Qatar: al-Syaikh Muhammad bin Khalīfah al-Asanī, 2004.

A., Abimanyu. 'Pengelolaan Dana Haji Dulu, Sekarang dan Masa Depan'. Realita Haji. Jakarta, 2014.

Ahmad, Khaliq, Mustafa Omar Mohammed, and Dzuljastri Abdul Razak. 'Case of Pilgrimage Funds Management Board (Lembaga Urusan Tabung Haji)'. IIUM Journal of Case Studies in Management 3, no. 2 (2012): 17-31. https://doi.org/10.1142/9789814508988.

Al-Fāsī, 'Alal. Maqāṣid Al-Sharīah Al-Islāmiyyah Wa Makārimuhā. 5th ed. Rabat: Dār al-Gharb al-Islāmī, 1993.

Al-Ghazālī, Abū Hāmid Muhammad ibn Muhammad. Al-Mustashfā Min IIm Al Ushūl. Beirut: Dar Ihyā at-Turāts al-Ārabi, n.d.

Al-Khīn, Mușțafā, Muștafā Al-Bughā, and 'Alī Al-Sharjabī. Al-Fiqh AlManhajī 'Alā Madhhab Al-Imām Al-Shāfi'î. 4th ed. Damaskus: Dār alQalam, 1996.

Al-Zuhaylī, Wahbah. Al-Fiqh Al-Islāmī Wa Adillatuh. 2nd ed. Damaskus: Dār al-Fikr al-'Arabī, 1985.

Bashnafar, Sa'īd 'Abd al-Qādir. Al-Mughnī Fī Fiqh Al-Haj Wa Al-'Umrah. Jeddah: Maktabah Al-'Ilm, 1993.

Buang, Ahmad Hidayat. 'Appreciation Of Syari'ah Principles In Property Management In Contemporary Malaysia Society'. Shariah Journal 16 (2008): 555-66.

DSN-MUI. Fatwa DSN-MUI No.122/DSN-MUI/II/2018 Tentang Pengelolaan Dana BPIH dan BPIH Khusus Berdasarkan Prinsip 
Syariah, Pub. L. No. 122/DSN-MUI/II/2018, 1 (2018).

Firdaus, Achmad. Maslahah Performa: Sistem Kinerja Untuk Mewujudkan Organisasi Berkemaslahatan. Yogyakarta: Deepublish, 2014.

Firdaus, Achmad, and Nurizal Ismail. 'Using Maslahah Performa As An Islamic Wealth Management System'. In Thematic Workshop on AlMal: Philosophy and Its Application in Islamic Perspective, UKMIRTI, Institute of Islamic Training Malaysia (ILIM), 1-13. Selangor, 2014.

Haji, Tabung. ‘5 Years Data \& Statistics'. Malaysia, 2019.

Indonesia, Kementerian Agama Republik. 'Laporan Keuangan Penyelenggaraan Ibadah Haji Tahun 2013', 2014.

IPHI. 'Pelaksanaan Haji Indonesia'. In Forum 'IJjtima' Ulama Komisi Fatwa Se-Indonesia IV'MUI 2012, 1-14, 2012.

Ishak, Mohd. Shuhaimi. 'Tabung Haji as an Islamic Financial Institution for Sustainable Economic Development'. In 2011 2nd International Conference on Humanities, Historical and Social Sciences IPEDR vol.17, 236-40, 2011.

Ismail, Nurizal. Maqashid Syariah dalam Ekonomi Islam. Yogyakarta: Smart WR, 2014.

Kementerian Agama Republik Indonesia. 'Laporan Evaluasi Penyelenggaraan Ibadah Haji 2013', 2013.

Masrifah, Atika Rukminastiti, and Achmad Firdaus. 'The Framework Of Maslahah Performa as Wealth Management System and Its Implication for Public Policy Objectives'. Media Syariah 18, no. 2 (2016).

MUI. Fatwa MUI No 6 Tahun 2010 (2010).

Munawwir, A.W., and Muhammad Fairuz. Kamus Al-Munawwir Indonesia-Arab Terlengkap. Pustaka Progressif, n.d.

Sābiq, Al-Sayyid. Fiqh Al-Sunnah. Kairo: Al-Fatḥ li al-I'lām al-'Arabī, n.d.

Shafii, Zurina, Zarinah Yusoff, and Shahizan Md Noh. Islamic Financial Planning and Wealth Management. Kuala Lumpur: IBFIM, 2013.

Subadi. 'Implementasi Kebijakan Pelayanan Haji Pada Kantor Kementerian Agama Kabupaten Bintan Provinsi Kepulauan Riau', 2013.

Zahrah, Muḥammad Abū. Ușūl Al-Fiqh. Kairo: Dār al-Fikr al-'Arabī, n.d. 
Ulfah Alfiyanti, Achmad Firdaus, Dede Abdul Fatah 